\title{
ANALISIS SENYAWA METABOLIT SEKUNDER DAN UJI TOKSISITAS EKSTRAK ETANOL BATANG TANAMAN PATAH TULANG (Euphorbia tirucalli L.) DENGAN METODE Brine Shrimp Lethality Test (BSLT)
}

\author{
Grace S. Baud $^{1)}$, Meiske S. Sangi ${ }^{1)}$, Harry S. J. Koleangan ${ }^{1)}$ \\ ${ }^{1)}$ Program Studi Kimia FMIPA UNSRAT, Manado \\ e-mail: gracebaud1@gmail.com; meiskesangi@gmail.com; koleanganharry@yahoo.com
}

\begin{abstract}
ABSTRAK
Telah dilakukan penelitian mengenai analisis senyawa metabolit sekunder dan uji toksisitas pada batang tanaman Patah tulang (Euphorbia tirucalli L.). Analisis senyawa metabolit sekunder dilakukan dengan skrining fitokimia yaitu senyawa alkaloid, flavonoid, triterpenoid, steroid, saponin dan tanin pada ekstrak segar dan kering batang tanaman Patah tulang. Penentuan toksisitas ekstrak etanol batang tanaman Patah tulang menggunakan metode Brine Shrimp Lethality Test (BSLT). Uji toksisitas digunakan hewan uji Artemia salina Leach sebagai bioindikator. Pada skrining fitokimia diperoleh positif flavonoid, tanin dan steroid sedangkan alkaloid, saponin dan triterpenoid negatif. Data pengujian toksisitas diperoleh dari analisis Lethality Concentration $50\left(\mathrm{LC}_{50}\right)$ yang dilakukan dengan metode probit menggunakan perangkat lunak SPSS 20.0 (untuk sistem operasi Windows). Hasil uji toksisitas ekstrak etanol batang Patah tulang menunjukkan bahwa ekstrak segar maupun kering bersifat sitotoksik dengan nilai $\mathrm{LC}_{50}$ $(7,994 \mathrm{ppm})$ untuk ekstrak etanol batang segar dan $\mathrm{LC}_{50}(9,940 \mathrm{ppm})$ untuk ekstrak etanol batang kering.
\end{abstract}

Kata kunci : Euphorbia tirucalli L., Senyawa metabolit sekunder, Toksisitas, Artemia salina Leach, $\mathrm{LC}_{50}$.

\section{ANALYSIS OF SECONDARY METABOLITE COMPOUNDS AND TOXICITY TEST OF STEM PLANT ETHANOL EXTRACTS OF PATAH TULANG (Euphorbia tirucalli L.) BY BRINE SHRIMP LETHALITY TEST'S METHOD (BSLT)}

\begin{abstract}
A research on the analysis of secondary metabolite compounds contained in the stem of patah tulang (Euphorbia tirucalli L.) and its toxicity had been done. The analysis was performed through phytochemical screening of alkaloids, flavonoids, triterpenoids, steroids, saponins and tannins on extracts of fresh and dried stem of the plant. Toxicity of ethanol extract of the stem was determined using Brine Shrimp Lethality Test (BSLT) method with Artemia salina Leach as bioindicator. Phytochemical screening showed positive results for flavonoids, tannins, and steroids and negative one for alkaloids, saponins, and triterpenoids. Toxicity data were obtained from Lethality Concentration $50\left(\mathrm{LC}_{50}\right)$ calculation trhrough probit analysis using SPSS 20.0 software (for Windows operating systems). Toxicity test showed that ethanol extracts of the fresh and dried stem were cytotoxic with $\mathrm{LC}_{50}$ value of $7.994 \mathrm{ppm}$ and $9.940 \mathrm{ppm}$, respectively.

Keywords: Euphorbia tirucalli L., Secondary metabolite compounds, Toxicity, Artemia salina Leach, $\mathrm{LC}_{50}$.

\section{PENDAHULUAN}

Sumber keanekaragaman hayati di Indonesia merupakan salah satu kekayaan alam yang berperan penting dalam berbagai lapisan masyarakat. Sebagai negara dengan

budaya yang masih kental akan pemanfaatan ragam tanaman tradisional untuk mengobati berbagai penyakit, masyarakat terutama di daerah pedesaan cenderung memakai tanaman sebagai obat tradisional untuk menyembuhkan penyakit yang diderita.
\end{abstract}


Tanaman menghasilkan senyawasenyawa metabolit sekunder yang bersifat toksik dan dapat digunakan untuk mengobati berbagai jenis penyakit pada manusia. Golongan senyawa metabolit sekunder adalah alkaloid, flavonoid, saponin, tanin, steroid dan triterpenoid (Harborne, 1987). Senyawa metabolit sekunder yang dihasilkan oleh tanaman dapat dianalisis kemampuan sitotoksiknya melalui metode Brine Shrimp Lethality Test (BSLT). Metode BSLT adalah salah satu cara yang digunakan untuk mengetahui kemampuan toksik terhadap sel (sitotoksik) dari suatu senyawa, yang dihasilkan oleh ekstrak tanaman dengan menggunakan larva udang Artemia salina Leach sebagai bioindikator (Kanwar, 2007). BSLT lazim digunakan karena lebih murah, mudah, cepat dan hasilnya akurat. Selain itu, metode ini telah terbukti memiliki hasil yang berkorelasi dengan kemampuan sitotoksik senyawa anti kanker (Meyer et al., 1982).

Salah satu tanaman obat yang digunakan oleh masyarakat adalah tanaman Patah tulang (Euphorbia tirucalli L.) yang merupakan salah satu spesies dari famili Euphorbiaceae (Plantamor, 2012). Menurut informasi dari masyarakat Bitung, tanaman Patah tulang ini merupakan tanaman obat yang digunakan secara empiris untuk mengobati patah tulang akibat kecelakaan atau terjatuh. Cara penggunaannya, batang tanaman ditumbuk halus dan ditempelkan pada daerah yang sakit. Tanaman Patah tulang juga dapat digunakan sebagai antikanker, anti-tumor, anti-inflamasi, penyakit kulit, dan pengobatan penyakit sifilis (Agral et al., 2013; Mangan, 2009).

Menurut hasil penelitian yang dilakukan oleh Absor (2006), ranting Patah tulang memiliki aktivitas antibakteri terhadap bakteri Bacillus subtilis, Staphylococcus aureus, Escherichia coli dan Pseudomonas aeruginosa. Selain itu, penelitian sebelumnya dari ekstrak metanol dan kloroform ranting tanaman patah tulang memiliki kemampuan toksik berturut-turut sebesar $332,2489 \mu \mathrm{g} / \mathrm{mL}$ dan $240,6432 \mu \mathrm{g} / \mathrm{mL}$ dan berpotensi sebagai pestisida. Senyawa yang terdapat dalam ekstrak metanol adalah flavonoid, tanin dan saponin sedangkan ekstrak kloroform hanya terdeteksi positif alkaloid (Oratmangun et al., 2014). Ekstrak ranting tanaman Patah tulang memiliki potensi sebagai tanaman obat yang terdeteksi memiliki senyawa metabolit sekunder, serta aktivitas toksik yang berbedabeda sesuai pada pelarut yang digunakan. Hal ini merupakan landasan pokok pemikiran untuk dilakukan analisis terhadap golongan senyawa metabolit sekunder dan aktivitas toksik dari ekstrak etanol batang tanaman Patah tulang.

\section{METODOLOGI PENELITIAN}

Alat - alat yang digunakan dalam penelitian ini adalah evaporator, desikator, pemanas listrik, timbangan digital, alat penggiling, alat-alat gelas, kertas saring, termometer, aerator, lampu, kaca pembesar (lup), senter, wadah uji, aluminium foil dan ayakan 65 mesh.

Bahan-bahan yang digunakan dalam penelitian ini adalah batang tanaman Patah tulang, telur A. salina Leach, dan akuades. Bahan-bahan kimia yang digunakan dalam penelitian ini adalah etanol $96 \%$ p.a, merkuri(II) klorida, kalium iodida, bismut sub nitrat, besi(III) klorida, asam klorida pekat, bubuk magnesium, asam asetat glasial, asam sulfat pekat dan garam dapur.

\section{Preparasi Sampel}

Sampel dibagi menjadi dua kelompok yaitu sampel segar dan sampel kering. Sampel segar dicuci bersih, ditiriskan lalu dikeringanginkan kemudian dipotong kecilkecil dan dihaluskan. Sampel kering, batang dicuci bersih kemudian ditiriskan lalu dikeringanginkan selama beberapa hari dan dipotong kecil-kecil, setelah itu diblender sampai halus dan disaring dengan ayakan 65 mesh.

\section{Ekstraksi Batang Tanaman Patah tulang}

Metode ekstraksi yang digunakan untuk sampel segar dan sampel kering adalah maserasi. Sebanyak $100 \mathrm{~g}$ sampel yang telah dihaluskan direndam dalam $500 \mathrm{~mL}$ etanol $96 \%$ p.a selama $2 \times 24$ jam sambil sesekali dikocok kemudian disaring, residu direndam kembali dengan etanol $96 \%$ p.a sebanyak 250 $\mathrm{mL}$ lalu dikocok dan disimpan selama $2 \times 24$ jam, kemudian disaring. Filtrat yang diperoleh pada maserasi pertama dan kedua dicampur dan dievaporasi, lalu dimasukkan dalam oven pada suhu $40-50^{\circ} \mathrm{C}$ untuk diperoleh ekstrak kental. Ekstrak kental yang telah diperoleh digunakan untuk analisis 
senyawa metabolit sekunder dan uji toksisitas.

\section{Skrining Fitokimia}

Sampel yang digunakan untuk skrining fitokimia adalah ekstrak etanol batang segar dan kering tanaman Patah tulang. Masing-masing pengujian dibuat duplo.

\section{Uji Alkaloid}

Sebanyak $2 \mathrm{~mL}$ ekstrak diuapkan di atas cawan porselin. Residu yang dihasilkan kemudian dilarutkan dengan $5 \mathrm{~mL} \mathrm{HCl} 2 \mathrm{M}$. Larutan yang diperoleh dibagi ke dalam 3 tabung reaksi. Tabung pertama berfungsi sebagai blanko, ditambahkan dengan 3 tetes $\mathrm{HCl} 2 \mathrm{M}$. Tabung kedua ditambahkan 3 tetes pereaksi Dragendorff dan tabung ketiga ditambahkan 3 tetes pereaksi Mayer. Pada pereaksi Dragendorff akan terbentuk endapan berwarna jingga sedangkan pereaksi Mayer akan terbentuk endapan kuning yang menandakan positif adanya alkaloid (Farsnworth, 1966).

\section{Uji Flavonoid}

Sebanyak $2 \mathrm{~mL}$ ekstrak ditambahkan dengan air panas secukupnya, kemudian dididihkan selama 5 menit lalu disaring. Filtrat sebanyak $5 \mathrm{~mL}$ ditambahkan $0,05 \mathrm{mg}$ serbuk $\mathrm{Mg}$ dan $1 \mathrm{~mL} \mathrm{HCl}$ pekat, kemudian dikocok kuat-kuat. Uji positif ditunjukkan dengan terbentuknya warna merah, kuning atau jingga (Harborne, 1987).

\section{Uji Tanin}

Sebanyak $1 \mathrm{~mL}$ ekstrak ditambahkan dengan beberapa tetes larutan besi(III)klorida $10 \%$. Jika terjadi warna biru tua atau hitam kehijauan menunjukkan adanya tanin (Jones dan Kinghorn, 2006; Robinson, 1995).

\section{Uji Steroid dan Triterpenoid}

Sebanyak $2 \mathrm{~mL}$ ekstrak ditambahkan $\mathrm{CH}_{3} \mathrm{COOH}$ glasial sebanyak 10 tetes dan $\mathrm{H}_{2} \mathrm{SO}_{4}$ pekat sebanyak 2 tetes. Larutan dikocok perlahan dan dibiarkan selama beberapa menit. Adanya steroid ditunjukan oleh warna biru atau hijau, sedangkan triterpenoid memberikan warna merah atau ungu (Harborne, 1987).

\section{Uji Saponin}

Sebanyak 2-3 mL ekstrak dimasukkan ke dalam tabung reaksi, kemudian ditambahkan $10 \mathrm{~mL}$ air panas lalu didinginkan, kemudian dikocok kuat-kuat selama 10 detik lalu ditambahkan 1 tetes $\mathrm{HCl}$ 2 N. Uji positif ditunjukkan dengan terbentuknya buih yang stabil setinggi 1-10 $\mathrm{cm}$ selama tidak kurang dari 10 menit (Depkes RI, 1995).

\section{Uji Toksisitas Menggunakan Metode BSLT}

Sampel yang digunakan untuk uji toksisitas adalah ekstrak etanol batang segar dan kering tanaman Patah tulang. Masingmasing pengujian dibuat duplo.

\section{Penyiapan larva $A$. salina Leach}

Sebanyak $1 \mathrm{~g}$ telur A. salina Leach. ditimbang kemudian direndam dalam $1 \mathrm{~L}$ air garam buatan untuk penetasan dan diberi penerangan serta diaerasi selama 48 jam. Air garam buatan dibuat dengan cara melarutkan $20 \mathrm{~g}$ garam dapur dalam $1 \mathrm{~L}$ air kemudian disaring.

\section{Penyiapan Larutan Stok}

Untuk pembuatan larutan stok, ekstrak dari sampel segar ditimbang sebanyak 200 mg kemudian dilarutkan sampai $100 \mathrm{~mL}$ dengan air garam buatan, selanjutnya dari larutan stok $2000 \mathrm{ppm}$ dibuat pengenceran 1000 ppm, 500 ppm, 100 ppm, 50 ppm, 25 ppm, 12,5 ppm dan 0 ppm sebagai kontrol tanpa penambahan ekstrak. Perlakuan yang sama dibuat untuk ekstrak sampel kering.

\section{Uji Toksisitas dan Analisis Statistik}

Disiapkan 6 wadah pengujian dan 1 wadah sebagai kontrol untuk masing-masing konsentrasi ekstrak sampel segar. Kemudian tiap konsentrasi larutan dimasukan 10 ekor larva udang A. salina Leach. Pengamatan dilakukan selama 1x24 jam terhadap kematian larva udang. Pengamatan jumlah larva udang yang mati dihitung tiap selang waktu 1 jam pada 6 jam pertama kemudian selang waktu 6 jam pada jam ke- 12, 18 dan 24. Perlakuan yang sama dilakukan untuk ekstrak sampel kering. Data hasil penelitian uji toksisitas diolah dengan analisis probit menggunakan SPSS 20.0 for Windows untuk mengetahui harga $\mathrm{LC}_{50}$. 
HASIL DAN PEMBAHASAN

Hasil skrining fitokimia menunjukan bahwa ekstrak etanol batang segar dan kering dari tanaman Patah tulang memiliki kandungan senyawa metabolit sekunder yang sama yaitu positif terdapat senyawa flavonoid, tanin, dan steroid. Tabel 1 menunjukan hasil skrining fitokimia terhadap ekstrak etanol batang tanaman Patah tulang.

Tabel 1. Hasil Skrining Fitokimia Batang Tanaman Patah tulang

Keterangan :

\begin{tabular}{|c|c|c|c|}
\hline \multirow{2}{*}{\multicolumn{2}{|c|}{ Uji }} & \multicolumn{2}{|c|}{ Hasil } \\
\hline & & \multirow{2}{*}{$\begin{array}{c}\mathrm{BK} \\
- \\
\end{array}$} & \multirow{2}{*}{ BS } \\
\hline Alkaloid & Meyer & & \\
\hline & Dragendorff & - & - \\
\hline \multicolumn{2}{|c|}{ Saponin } & - & - \\
\hline \multicolumn{2}{|c|}{ Flavonoid } & + & + \\
\hline \multicolumn{2}{|c|}{ Steroid } & + & + \\
\hline \multicolumn{2}{|c|}{ Triterpenoid } & - & - \\
\hline \multicolumn{2}{|c|}{ Tanin } & + & + \\
\hline
\end{tabular}

$\mathrm{BS}=$ batang segar, $\mathrm{BK}=$ batang kering, $(-)$ = senyawa tidak terdeteksi, $(+)$ = senyawa terdeteksi

Alkaloid

Alkaloid yang diuji dengan menggunakan pereaksi Dragendorff akan menghasilkan endapan berwarna jingga, sedangkan dengan pereaksi Mayer akan menghasilkan endapan berwarna putih kekuningan, penambahan asam klorida bertujuan untuk mengekstrak alkaloid yang bersifat basa dengan menggunakan larutan asam (Farnsworth, 1966; Jones dan Kinghorn, 2006). Hasil skrining fitokimia menunjukan tidak adanya endapan, yang berarti bahwa kedua ekstrak etanol batang tanaman Patah tulang tidak terdapat senyawa alkaloid.

\section{Flavonoid}

Flavonoid dapat diuji keberadaannya menggunakan $\mathrm{Mg}$ dan $\mathrm{HCl}$ pekat. Senyawa flavonoid dapat menghasilkan warna merah, kuning atau jingga ketika tereduksi dengan $\mathrm{Mg}$ dan $\mathrm{HCl}$ (Harborne, 1987). Hasil skrining fitokimia menunjukan kedua ekstrak etanol batang tanaman Patah tulang berwarna kuning dan positif terdapat flavonoid. Contoh reaksi terbentuknya senyawa flavonoid ketika direduksi oleh $\mathrm{Mg}$ dan $\mathrm{HCl}$ ditunjukan pada gambar 1 . Beragam warna yang dihasilkan ketika pengujian, dipengaruhi oleh pelarut dan prosedur yang digunakan (Sangi et al., 2008).

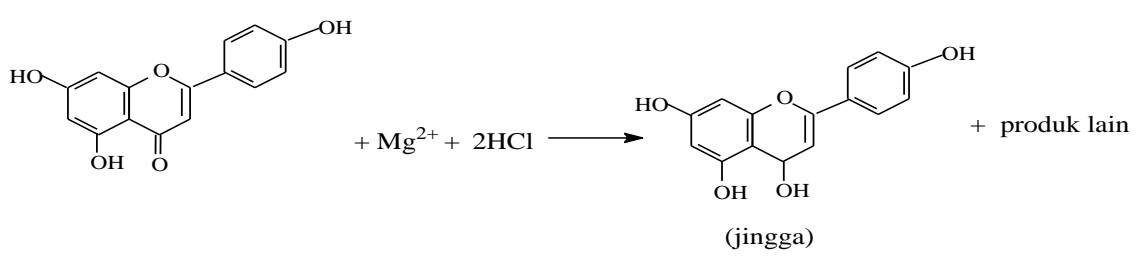

Gambar 1. Contoh reaksi identifikasi senyawa flavonoid (Harborne, 1987)

\section{Tanin}

Identifikasi terhadap senyawa tanin dilakukan melalui penambahan $\mathrm{FeCl}_{3}$. Senyawa tanin adalah senyawa yang bersifat polar karena adanya gugus $\mathrm{OH}$, ketika ditambahkan $\mathrm{FeCl}_{3} \quad 10 \%$ akan terjadi perbahan warna seperti biru tua atau hijau kehitaman yang menandakan adanya senyawa tanin (Jones dan Kinghorn, 2006; Robinson, 1991).

Menurut Sangi et al. (2008), tanin terhidrolisis akan menunjukan warna biru kehitaman sedangkan tanin terkondensasi akan menunjukan warna hijau kehitaman ketika penambahan $\mathrm{FeCl}_{3}$. Dari hasil skrining fitokimia pada kedua ekstrak etanol batang tanaman Patah tulang, diperoleh hasil warna hijau kehitaman yang berarti positif terdapat tanin terkondensasi.

\section{Steroid Dan Triterpenoid}

Pengujian steroid dan triterpenoid dalam $\mathrm{CH}_{3} \mathrm{COOH}$ glasial dengan $\mathrm{H}_{2} \mathrm{SO}_{4}$ pekat didasarkan pada kemampuan senyawa 
steroid dan triterpenoid dalam membentuk warna biru atau hijau untuk steroid, dan merah atau ungu untuk triterpenoid. Steroid dan triterpenoid merupakan senyawa yang dapat terekstraksi dengan pelarut non polar atau semi polar (Harborne, 1987; Nurjanah, 2011).

Hasil skrining fitokimia menunjukan kedua ekstrak etanol batang tanaman Patah tulang memberikan warna hijau dan positif terdapat steroid. Warna hijau yang terbentuk disebabkan oleh ekstrak etanol batang tanaman Patah tulang yang bereaksi terhadap asam $\left(\mathrm{CH}_{3} \mathrm{COOH}\right.$ glasial dan $\mathrm{H}_{2} \mathrm{SO}_{4}$ pekat $)$.
Saponin merupakan senyawa aktif permukaan yang mudah terdeteksi melalui kemampuannya dalam membentuk busa. Komponen ikatan glikosida yang terdapat didalam saponin menyebabkan senyawa ini cenderung bersifat polar (Harborne, 1987; Sangi et al., 2008). Keberadaan saponin positif jika ekstrak yang diuji membentuk busa setinggi $1-10 \mathrm{~cm}$ dengan selang waktu \pm 10 menit (Depkes RI, 1995). Berdasarkan hasil skrining fitokimia menunjukan ekstrak etanol batang tanaman Patah tulang tidak terdapat saponin karena tidak membentuk busa.

\section{Saponin}

Tabel 2. Pengaruh Variasi Konsentrasi Ekstrak Batang Segar Tanaman Patah Tulang terhadap Kematian Rata-rata Larva Artemia salina Leach

\begin{tabular}{|c|c|c|c|c|c|c|c|}
\hline \multirow{2}{*}{$\begin{array}{c}\text { Waktu } \\
\text { (Jam) }\end{array}$} & \multicolumn{7}{|c|}{ Konsentrasi (ppm) } \\
\hline & 0 & 12,5 & 25 & 50 & 100 & 500 & 1000 \\
\hline 1 & 0 & 0 & 0 & 0 & 3.5 & 7 & 10 \\
\hline 2 & 0 & 0 & 0 & 1 & 0 & 0 & 0 \\
\hline 3 & 0 & 0 & 0 & 0 & 0 & 0 & 0 \\
\hline 4 & 0 & 0 & 0 & 0 & 0 & 0 & 0 \\
\hline 5 & 0 & 0 & 0 & 0 & 0 & 0 & 0 \\
\hline 6 & 0 & 0 & 2.5 & 1.5 & 3 & 3 & 0 \\
\hline 12 & 0 & 1 & 4.5 & 4 & 1.5 & 0 & 0 \\
\hline 18 & 0 & 0 & 1.5 & 1.5 & 0.5 & 0 & 0 \\
\hline 24 & 0 & 5 & 0 & 1.5 & 1.5 & 0 & 0 \\
\hline Total & 0 & 6 & 8.5 & 9.5 & 9.5 & 10 & 10 \\
\hline $\begin{array}{c}\text { \% Kematian } \\
\text { Larva }\end{array}$ & 0 & $60 \%$ & $85 \%$ & $95 \%$ & $95 \%$ & $100 \%$ & $100 \%$ \\
\hline $\mathrm{LC}_{50}$ & \multicolumn{7}{|c|}{ 7,994ppm } \\
\hline
\end{tabular}

Tabel 3. Pengaruh Variasi Konsentrasi Ekstrak Batang Kering Tanaman Patah Tulang terhadap Kematian Rata-rata Larva Artemia salina Leach

\begin{tabular}{|c|c|c|c|c|c|c|c|}
\hline \multirow{2}{*}{$\begin{array}{c}\text { Waktu } \\
(\text { Jam })\end{array}$} & \multicolumn{7}{|c|}{ Konsentrasi (ppm) } \\
\hline & 0 & 12,5 & 25 & 50 & 100 & 500 & 1000 \\
\hline 1 & 0 & 0 & 0 & 0 & 0 & 0 & 0 \\
\hline 2 & 0 & 0 & 0 & 0 & 0 & 0 & 5.5 \\
\hline 3 & 0 & 0 & 0 & 0 & 0 & 4.5 & 1.5 \\
\hline 4 & 0 & 0 & 0 & 0 & 0 & 0 & 1 \\
\hline 5 & 0 & 0 & 0 & 0 & 0 & 0 & 1 \\
\hline 6 & 0 & 1 & 1 & 3 & 2.5 & 1 & 1 \\
\hline 12 & 0 & 2.5 & 3 & 2.5 & 3.5 & 1.5 & 0 \\
\hline 18 & 0 & 1 & 1.5 & 1.5 & 1.5 & 1 & 0 \\
\hline 24 & 0 & 1 & 2 & 1.5 & 1.5 & 2 & 0 \\
\hline Total & 0 & 5.5 & 7.5 & 8.5 & 9 & 10 & 10 \\
\hline $\begin{array}{c}\text { \% Kematian } \\
\text { Larva }\end{array}$ & 0 & $55 \%$ & $75 \%$ & $85 \%$ & $90 \%$ & $100 \%$ & $100 \%$ \\
\hline LC50 & & & $9,940 \mathrm{ppm}$ & & & 10 \\
\hline
\end{tabular}





\section{Uji Toksisitas}

Penelitian ini menunjukan bahwa kedua ekstrak etanol batang tanaman Patah tulang masing-masing memiliki kemampuan toksik yang dapat membunuh larva Artemia salina Leach. Konsentrasi yang diuji dalam penelitian ini untuk ekstrak etanol batang tanaman Patah tulang segar dan kering adalah 1000, 500, 100, 50, 25 dan 12,5 ppm. Penelitian ini juga dibuat konsentrasi 0 ppm sebagai kontrol, tanpa penambahan ekstrak. Larva yang digunakan berumur 48 jam, karena menurut McLaughlin dan Roger (1998) kondisi larva yang tepat untuk uji hayati yaitu pada usia 48 jam, dimana anggota tubuh larva sudah lengkap (Muaja, 2013). Tabel 4 dan 5 menujukan hasil penelitian pengaruh variasi konsentrasi terhadap kematian rata-rata larva A. salina Leach.

Dari tabel 4 dan 5 menunjukan angka kematian rata-rata larva A.salina Leach pada ekstrak etanol batang segar tanaman Patah tulang lebih besar daripada ekstrak etanol batang kering tanaman Patah tulang. Hasil analisis probit dengan menggunakan SPSS 20.0 for windows untuk ekstrak etanol batang segar menunjukan nilai $\mathrm{LC}_{50}$ sebesar 7,994ppm sedangkan, ekstrak etanol batang kering memiliki nilai $\mathrm{LC}_{50}$ sebesar 9,940ppm.

Menurut Meyer et al. (1982) menuliskan bahwa suatu ekstrak memiliki aktivitas toksik apabila dapat membunuh $50 \%$ hewan uji pada konsentrasi $<1000$ $\mu \mathrm{g} / \mathrm{mL}$. Selain itu, McLaughlin et al. (1991) menuliskan nilai $\mathrm{LC}_{50}<30 \mu \mathrm{g} / \mathrm{mL}$ bersifat sitotoksik, $30-200 \mu \mathrm{g} / \mathrm{mL}$ berpotensi sebagai antibakteri sedangkan $200-1000 \mu \mathrm{g} / \mathrm{mL}$ berpotensi sebagai pestisida. Berdasarkan hasil analisis probit $\mathrm{LC}_{50}$ pada ekstrak etanol batang segar dan kering tanaman Patah tulang menunjukan bahwa keduanya memiliki sifat sitotoksik.

\section{KESIMPULAN}

1. Analisis senyawa metabolit sekunder pada ekstrak etanol batang segar dan kering tanaman Patah tulang positif terdapat senyawa flavonoid, steroid dan tanin.

2. Uji toksisitas dengan metode BSLT terhadap larva Artemia salina Leach menunjukan bahwa ekstrak etanol batang segar dan kering tanaman Patah tulang bersifat sitotoksik serta memiliki nilai $\mathrm{LC}_{50}$ berturut-turut 7,994ppm dan 9,940ppm.

\section{DAFTAR PUSTAKA}

Absor, U. 2006. Aktivitas Antibakteri Ranting Patah Tulang (Euphorbia tirucalli. Linn). [skripsi]. FMIPA IPB, Bogor.

Agral, O., Fatimawali., Yamlean, P. dan Supriati, H.S. 2013. Formulasi dan Uji Kelayakan Sediaan Krim Anti Inflamasi Getah Tanaman Patah Tulang (Euphorbia tirucalli L.). Pharmacon Jurnal Ilmiah Farmasi UNSRAT. 2:1-3.

Depkes RI. 1995. Farmakope Indonesia. Departemen Kesehatan Republik Indonesia, Jakarta.

Farsnworth, N. R. 1966. Biological and Phytochemical Screening of Plant. Journal of Pharmaceutical Sciences. 55: 59.

Harborne, J.B. 1987. Metode Fitokimia. Terjemahan: Padmawinata, $\mathrm{K}$ dan Soediro, I. Institut Teknologi Bandung, Bandung.

Jones, W.P., Kinghorn, A.D. 2006. Extraction of Plant Secondary Metabolites. In: Sharker, S.D. Latif Z., Gray A.L, eds. Natural Product Isolation. $2^{\text {nd }}$ edition. Humana Press. New Jersey.

Mangan, Y. 2009. Solusi Sehat Mencegah dan Mengatasi Kanker. Agromedia pustaka, Jakarta.

McLaughlin, J.L dan Rogers, L.L. 1998. The Use Of Biological Assays To Evaluate Botanicals. Drug Information Journal. 32:513-524.

McLaughlin, J.L., Chang, C. J., dan Smith, D. L. 1991. Bench-Top, Bioassay for The Discovery of Bioactive Naturals Products, An Update, Natural Product Chemistry. Elseiveir. Amsterdam.

Meyer, B.N., Ferrigni, N.R., Putnam, J.E., Jacobsen, L. B., Nichols, D. E. dan McLaughlin, J.L. 1982. Brine Shrimp: A Convenient General Bioassay for Active Plant Constituents. Journal of Medicinal Plant Research. 45:31-34. 
Muaja, A. D. 2013. Uji Toksisitas dengan Metode BSLT dan Analisis Daun Soyogik (Saurauia bracteosa DC) dengan Metode Soxhletasi. [Skripsi]. FMIPA UNSRAT, Manado.

Plantamor. 2012. Your plant database: Situs dunia tumbuhan. http://www.plantamor.com/index.ph p?plant $=571$ [diakses pada 10 agustus 2014).

Robinson, T. 1995. Kandungan Organik Tumbuhan Tingkat Tinggi. ITB, Bandung.

Sangi, M., Runtuwene, M.R.J., Simbala, H.E.I. dan Makang, V.M.A. 2008. Analisis Fitokimia Tumbuhan Obat di Kabupaten Minahasa Utara. Chemistry Progress. 1:47-53.

Sangi, M., L. Momuat dan M. Kumaunang. 2012. Uji Toksisitas dan Skrining Fitokimia Tepung Gabah Pelepah Aren (Arenga pinnata). Jurnal Ilmiah Sains. 12:128-134. 